\title{
QbD approach to HPLC method development and validation of ceftriaxone sodium
}

Krunal Y. Patel ${ }^{1}$, Zarna R. Dedania ${ }^{1 *}$, Ronak R. Dedania ${ }^{1}$ and Unnati Patel ${ }^{2}$

\begin{abstract}
Background: Quality by design $(\mathrm{QbD})$ refers to the achievement of certain predictable quality with desired and predetermined specifications. A quality-by-design approach to method development can potentially lead to a more robust/rugged method due to emphasis on risk assessment and management than traditional or conventional approach. An important component of the $\mathrm{QbD}$ is the understanding of dependent variables, various factors, and their interaction effects by a desired set of experiments on the responses to be analyzed. The present study describes the risk based HPLC method development and validation of ceftriaxone sodium in pharmaceutical dosage form.

Results: An efficient experimental design based on central composite design of two key components of the RPHPLC method (mobile phase and pH) is presented. The chromatographic conditions were optimized with the Design Expert software 11.0 version, i.e., Phenomenex ODS column C18 (250 mm × 4.6 mm, $5.0 \mu$ ), mobile phase used acetonitrile to water (0.01\% triethylamine with $\mathrm{pH} 6.5)(70: 30, \mathrm{v} / \mathrm{v})$, and the flow rate was $1 \mathrm{ml} / \mathrm{min}$ with retention time $4.15 \mathrm{~min}$. The developed method was found to be linear with $\mathrm{r}^{2}=0.991$ for range of $10-200 \mu \mathrm{g} / \mathrm{ml}$ at $270 \mathrm{~nm}$ detection wavelength. The system suitability test parameters, tailing factor and theoretical plates, were found to be 1.49 and 5236. The \% RSD for intraday and inter day precision was found to be $0.70-0.94$ and $0.55-$ 0.95 respectively. The robustness values were less than $2 \%$. The assay was found to be $99.73 \pm 0.61 \%$. The results of chromatographic peak purity indicate the absence of any coeluting peaks with the ceftriaxone sodium peak. The method validation parameters were in the prescribed limit as per ICH guidelines.

Conclusion: The central composite design experimental design describes the interrelationships of mobile phase and $\mathrm{pH}$ at three different level and responses to be observed were retention time, theoretical plates, and peak asymmetry with the help of the Design Expert 11.0 version. Here, a better understanding of the factors that influence chromatographic separation with greater confidence in the ability of the developed HPLC method to meet their intended purposes is done. The QbD approach to analytical method development was used for better understanding of method variables with different levels.
\end{abstract}

Keywords: Quality by design, HPLC, Ceftriaxone sodium, Design approach

\footnotetext{
* Correspondence: zarnadedania.pharmacy@bmefcolleges.edu.in

'Department of Quality Assurance, Bhagwan Mahavir College of Pharmacy,

Vesu, Surat, Gujarat, India

Full list of author information is available at the end of the article
}

\section{Springer Open}

(c) The Author(s). 2021 Open Access This article is licensed under a Creative Commons Attribution 4.0 International License, which permits use, sharing, adaptation, distribution and reproduction in any medium or format, as long as you give appropriate credit to the original author(s) and the source, provide a link to the Creative Commons licence, and indicate if changes were made. The images or other third party material in this article are included in the article's Creative Commons licence, unless indicated otherwise in a credit line to the material. If material is not included in the article's Creative Commons licence and your intended use is not permitted by statutory regulation or exceeds the permitted use, you will need to obtain permission directly from the copyright holder. To view a copy of this licence, visit http://creativecommons.org/licenses/by/4.0/. 


\section{Background}

A QbD is defined as "A systemic approach to the method development that begins with predefined objectives and emphasizes product and process understanding and process control, based on sound science and quality risk management [1]." The QbD approach emphasizes product and process understanding with quality risk management and controls, resulting in higher assurance of product quality, regulatory flexibility, and continual improvement. The QbD method was based on the understanding and implementation of guidelines $\mathrm{ICH}$ Q8 Pharmaceutical Development, ICH Q9 Quality Risk Management, and ICH Q10 Pharmaceutical Quality System [2-4]. Analytical science is considered to be an integral part of pharmaceutical product development and hence go simultaneously during the entire product life cycle. Analytical QbD defined as a science and riskbased paradigm for analytical method development, endeavoring for understanding the predefined objectives to control the critical method variables affecting the critical method attributes to achieve enhanced method performance, high robustness, ruggedness, and flexibility for continual improvement $[5,6]$. The result of analytical $\mathrm{QbD}$ is well known, fit for purpose, and robust method that reliably delivers the intended output over its lifecycle, similar to the process QbD [7, 8]. For QbD, HPLC methods, robustness, and ruggedness should be tested earlier in the development stage of the method to ensure the efficiency of the method over the lifetime of the product [9]. Otherwise, it can take considerable time and energy to redevelop, revalidate, and retransfer analytical methods if a non-robust or non-rugged system is adapted. The major objective of AQbD has been to identify failure modes and establish robust method operable design region or design space within meaningful system suitability criteria and continuous life cycle management. Literature survey reveals QbD approaches for HPLC method were reported [10-13].

The current work intends to develop and optimize the HPLC method for ceftriaxone sodium in pharmaceutical dosage form by quality-by-design approach.

\section{Methods}

\section{Materials}

Ceftriaxone sodium was procured as gift sample Salvavidas Pharmaceutical Pvt. Ltd., Surat, Gujarat. All other reagents and chemicals used were of analytical grade, and solvents were used were of HPLC grade. The marketed formulations MONOCEF $250 \mathrm{mg}$ by Aristo were used for assay.

\section{Instruments and reference standards}

The HPLC WATERS-2695 with Detector-UV VIS Dual Absorbance Detector WATERS-2487. C-18 column
$(150 \mathrm{~mm} \times 4.6 \mathrm{~mm} \times 5 \mu \mathrm{m}$ particle size $)$ was used at ambient temperature.

\section{Chromatographic conditions}

The Phenomenex C-18 column $(250 \mathrm{~mm} \times 4.6 \mathrm{~mm}$ having $5.0 \mu \mathrm{m}$ particle size equilibrated with a mobile phase consisting of acetonitrile to water (70:30, v/v)) was used. The mobile phase pH 6.5 was adjusted with $0.01 \%$ triethylamine. The flow rate was kept at $1 \mathrm{ml} / \mathrm{min}$, and column was set at ambient temperature. Eluents were supervised using a PDA detector at $270.0 \mathrm{~nm}$. A satisfactory separation and peak symmetry for the drug were obtained with the above chromatographic condition. The HPLC method for ceftriaxone sodium was optimized for various parameters: mobile phase and $\mathrm{pH}$ as two variables at three different levels using central composite design.

\section{Preparation of reference standard solution}

The $1000 \mu \mathrm{g} / \mathrm{ml}$ standard stock solution was prepared by dissolving an accurately $25 \mathrm{mg}$ of ceftriaxone sodium in $25 \mathrm{ml}$ methanol. The stock solution was further diluted to a sub-stock $100 \mu \mathrm{g} / \mathrm{ml}$. The $10 \mu \mathrm{g} / \mathrm{ml}$ solution was prepared by diluting $1 \mathrm{ml}$ of sub-stock solution to $10 \mathrm{ml}$ with methanol.

\section{Selection of detection wavelength}

Ten $\mu \mathrm{g} / \mathrm{ml}$ ceftriaxone sodium was scanned in the range of $200-400 \mathrm{~nm}$, and wavelength maxima $270 \mathrm{~nm}$ was selected as detection wavelength.

\section{HPLC method development by QbD approach}

HPLC method development by Analytical QbD was as follows.

\section{Selection of quality target product profile}

The QTPP plays an important role for identifying the variables that affect the QTPP parameters. The retention time, theoretical plates, and peak asymmetry were identified as QTPP for proposed HPLC method [14, 15].

\section{Determine critical quality attributes}

The CQAs are the method parameters that are directly affect the QTPP. The mobile phase composition and $\mathrm{pH}$ of buffer were two critical method parameters required to be controlled to maintain the acceptable response range of QTPP [16].

\section{Factorial design}

After defining the QTPP and CQAs, the central composite experimental design was applied to optimization and selection of two key components: mobile phase and $\mathrm{pH}$ of HPLC method. The various interaction effects and quadratic effects of the mobile phase composition and 
$\mathrm{pH}$ of buffer solution on the retention time, theoretical plates, and peak asymmetry was studied using central composite statistical screening design.

A 2-factor, mobile phase composition and $\mathrm{pH}$ of buffer solution at 3 different levels, design was used with Design Expert ${ }^{\circ}$ (Version 11.0, Stat-Ease Inc., and M M), the best suited response for second-order polynomial exploring quadratic response surfaces [15].

$$
\begin{aligned}
\mathrm{Y}= & \beta_{0}+\beta_{1} \mathrm{~A}+\beta_{2} \mathrm{~B}+\beta_{12} \mathrm{AB}+\beta_{11} \mathrm{~A}_{2}+\beta_{22} \mathrm{~B}_{2} \mathrm{~B} \\
& +\beta_{22} \mathrm{~B}_{2} \mathrm{~A}+\beta_{11} \mathrm{~A}_{2}
\end{aligned}
$$

where $\mathrm{A}$ and $\mathrm{B}$ are independent variables coded for levels, $\mathrm{Y}$ is the measured response associated with each combination of factor level, $\beta 0$ is an intercept, and $\beta 1$ to $\beta 22$ are regression coefficients derived from experimental runs of the observed experimental values of Y. Interaction and quadratic terms respectively represent the terms $\mathrm{AB}, \mathrm{A} 2$, and $\mathrm{B} 2$.

Since multivariable interaction of variables and process parameter have been studied, the factors were selected based on preliminary analysis [17]. As independent variables, mobile phase composition and $\mathrm{pH}$ of buffer were chosen and shown in Table 1. The dependent variables were retention time, peak area, and peak asymmetry as dependent variables for proposed independent variables [18].

\section{Evaluation of experimental results and selection of final method conditions}

Using the CCD approach, these method conditions were assessed. At the first step, the conditions for retention time, theoretical plates, and peak asymmetry were evaluated. For ceftriaxone sodium, this resulted in distinct chromatographic conditions. The proven acceptable ranges from robust regions where the deliberate variations in the method parameters do not affect the quality. This ensures that the method does not fail downstream during validation testing. If the modeling experiments do not have the desired response, the variable needs to be optimized at different levels until the responses were within the acceptable ranges [19]. The best suited chromatographic conditions shall be optimized using the Design Expert tools.

Table 1 Coded values for independent variables

\begin{tabular}{lllll}
\hline Factor & $\begin{array}{l}\text { Coded } \\
\text { values } \\
\text { given } \\
\text { factor }\end{array}$ & Levels & & \\
\cline { 2 - 5 } & $\mathrm{A}$ & $25: 75$ & $\mathbf{0}$ & $\mathbf{+ 1}$ \\
\hline Acetonitrile to water & $\mathrm{A}$ & 6.5 & 5.5 & $35: 65$ \\
$\mathbf{p H}$ of buffer & $\mathrm{B}$ & 6.5 \\
\hline
\end{tabular}

\section{Risk assessment}

The optimized final method is selected against the attributes of the method like that the developed method is efficient and will remain operational throughout the product's lifetime. A risk-based approach based on the QbD principles set out in ICH Q8 and ICH Q9 guidelines was applied to the evaluation of method to study the robustness and ruggedness [20]. The parameters of the method or its performance under several circumstances, such as various laboratories, chemicals, analysts, instruments, reagents, and days, were evaluated for robustness and ruggedness studies [21].

\section{Implement a control strategy}

A control strategy should be implemented after the development of method. The analytical target profile was set for the development of the analytical control strategy. The analytical control strategy is the planned set of controls that was derived from the understanding of the various parameters, i.e., fitness for purpose, analytical procedure, and risk management. All these parameters ensure that both performance of the method and quality outputs are within the planned analytical target profile. Analytical control strategy was planned for sample preparation, measurement, and replicate control operations [22].

\section{Continual improvement for managing analytical life cycle}

The best way in the management of analysis lifecycle is doing a continual improvement that can be implemented by monitoring the quality consistency and periodic maintenance of HPLC instrument, computers, and updating of software and other related instrument and apparatus can be done within laboratory [23].

\section{Analytical method validation}

Method validation is a documented evidence which provides a high degree of assurance for a specific method that the process used to confirm the analytical process is suitable for its intended use. The developed HPLC method for estimation ceftriaxone sodium was validated as per ICH Q2 (R1) guidelines [24].

\section{Linearity}

The linearity of ceftriaxone sodium was evaluated by analyzing 5 independent levels concentration range of $10-200 \mu \mathrm{g} / \mathrm{ml}$. The calibration curve was constructed by plotting peak area on $\mathrm{y}$ axis versus concentration on $\mathrm{x}$ axis. The regression line equation and correlation coefficient values were determined.

\section{Precision}

Repeatability calculated by the measurement of six samples $100 \mu \mathrm{g} / \mathrm{ml}$ ceftriaxone sodium. The intraday and interday precision were determined by analyzing three 
Table 2 Optimization of parameters for analysis of ceftriaxone sodium using CCD

\begin{tabular}{llllll}
\hline Run & $\begin{array}{l}\text { Factor-1 } \\
\text { Acetonitrile to water }\end{array}$ & $\begin{array}{l}\text { Factor-2 } \\
\mathbf{p H}\end{array}$ & $\begin{array}{l}\text { Response-1 } \\
\text { Retention time }\end{array}$ & $\begin{array}{l}\text { Response-2 } \\
\text { Theoretical plate }\end{array}$ & $\begin{array}{l}\text { Response-3 } \\
\text { Peak asymmetry }\end{array}$ \\
\hline $\mathbf{1}$ & $70: 30$ & 6.5 & 4.033 & 5263 & 1.41 \\
$\mathbf{2}$ & $70: 30$ & 7.5 & 8.162 & 1798 & 1.66 \\
$\mathbf{3}$ & $75: 25$ & 5.5 & 3.468 & 1065 & 1.99 \\
$\mathbf{4}$ & $75: 25$ & 7.5 & 8.125 & 2352 & 1.99 \\
$\mathbf{5}$ & $65: 35$ & 6.5 & 4.017 & 8562 & 1.02 \\
$\mathbf{6}$ & $65: 35$ & 5.5 & 3.256 & 1523 & 1.96 \\
$\mathbf{7}$ & $75: 25$ & 6.5 & 4.018 & 5385 & 1.55 \\
$\mathbf{8}$ & $70: 30$ & 6.5 & 4.033 & 5263 & 1.41 \\
$\mathbf{9}$ & $70: 30$ & 5.5 & 3.265 & 2046 & 1.66 \\
$\mathbf{1 0}$ & $65: 35$ & 7.5 & 8.126 & 1689 & 1.85 \\
$\mathbf{1 1}$ & $70: 30$ & 6.5 & 4.033 & 5263 & 1.41 \\
\hline
\end{tabular}

different concentrations of ceftriaxone sodium 100, 150, and $200 \mu \mathrm{g} / \mathrm{ml}$ concentrations at three times, on the same day at an interval of $2 \mathrm{~h}$ and for three different days. The acceptance limit for \% RSD was less than 2.

\section{Accuracy}

The accuracy of the method was determined by calculating by recovery study from marketed formulation by at three levels $80 \%, 100 \%$, and $120 \%$ of standard addition.
The \% recovery of ceftriaxone sodium was calculated. The acceptance limit for \% recovery as per ICH guidelines was $98-102 \%$ of standard addition.

\section{$\angle O D$ and $\angle O Q$}

The lowest drug concentration that can be accurately identified and separated from the background is referred to as a detection limit (LOD) and that can be quantified at the lowest concentration is referred to as LOQ, i.e.,

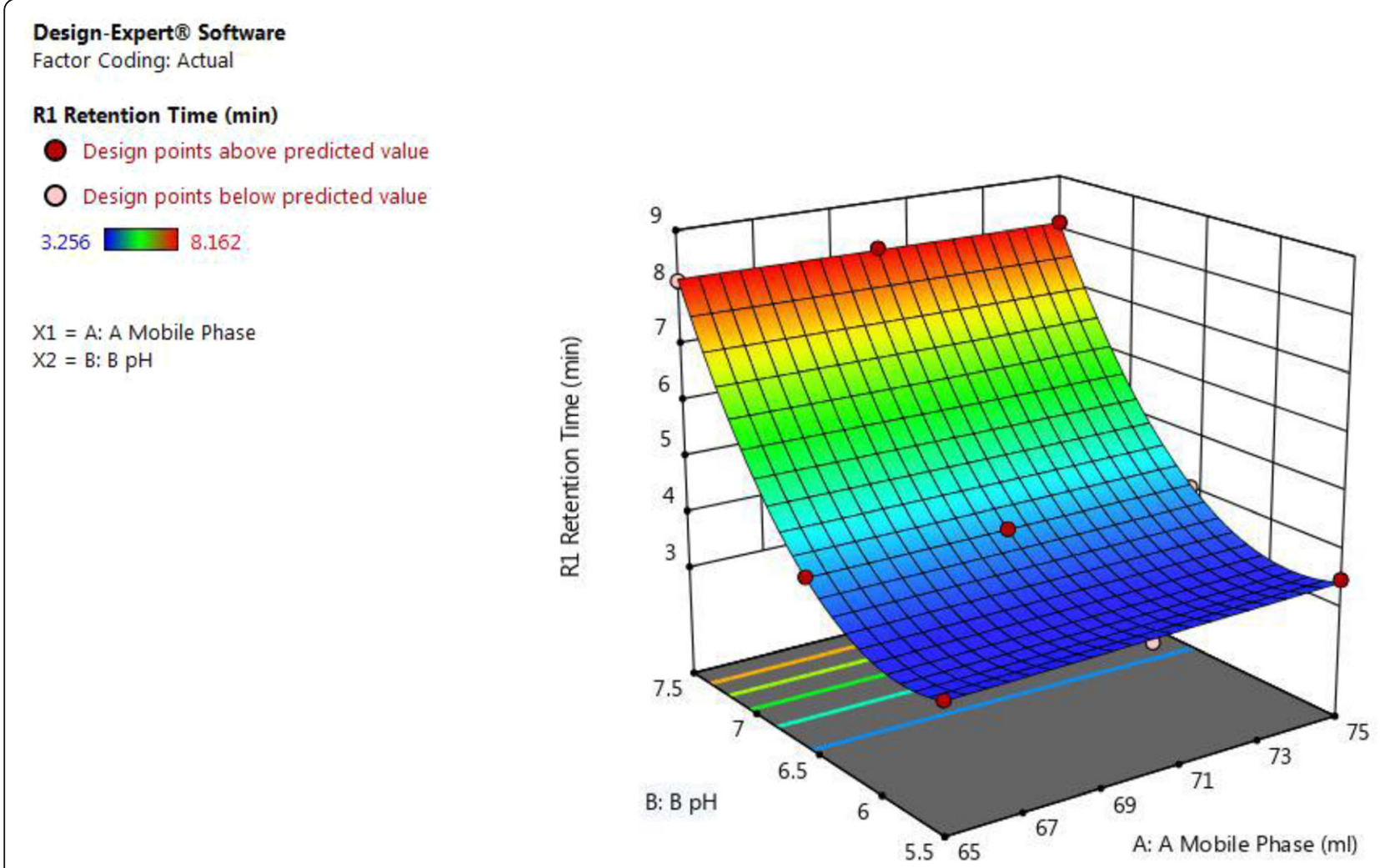

Fig. 1 3D surface plot for effect of combination of factors on R1 retention time of ceftriaxone sodium by using central composite design 


\section{Design-Expert Software}

Factor Coding: Actual

\section{R3 Peak Assymetry}

Design points above predicted value

Design points below predicted value

1.02

1.99

$\mathrm{X} 1=\mathrm{A}:$ A Mobile Phase

$\mathrm{X} 2=\mathrm{B}: \mathrm{B}$ pH

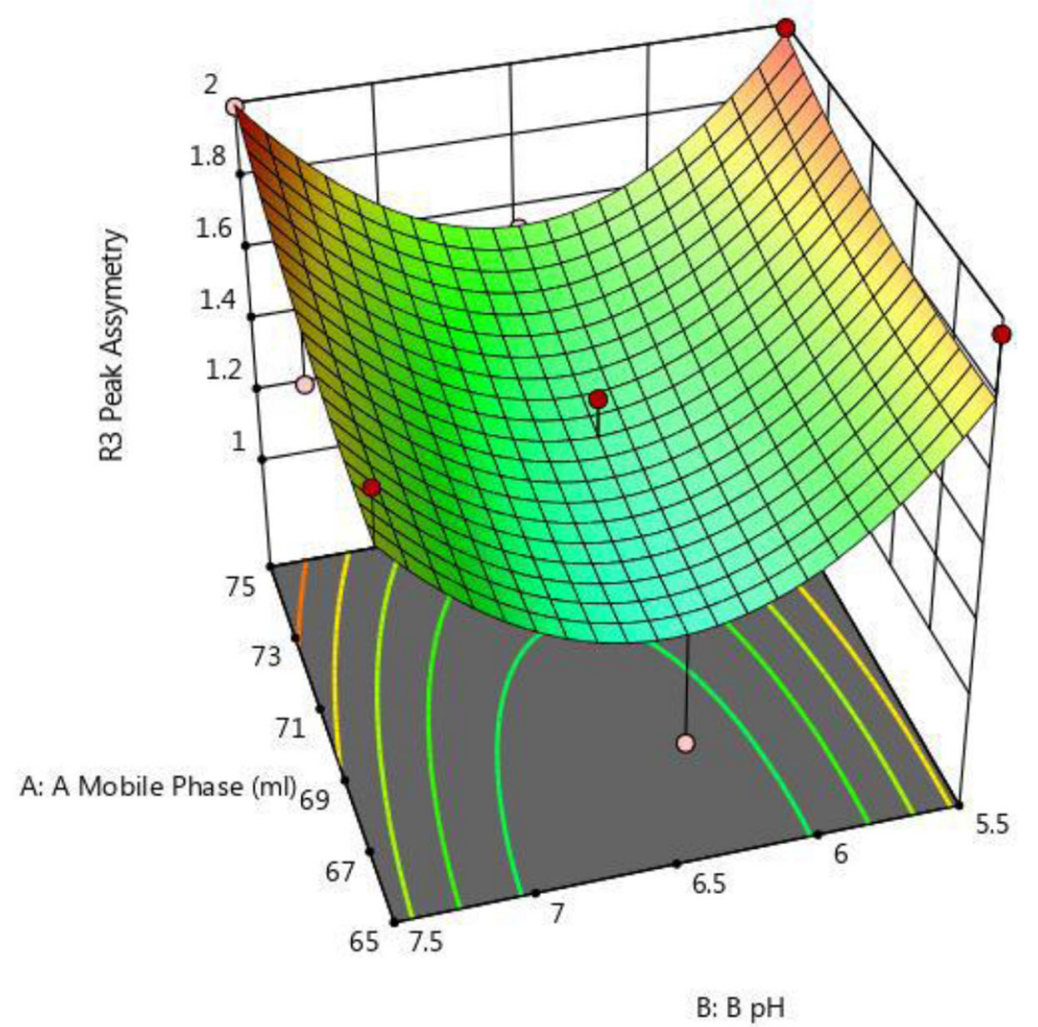

Fig. 2 3D surface plot for effect of combination of factors on R2 theoretical plate ceftriaxone sodium by using central composite design

Design-Expert Software

Factor Coding: Actual

\section{R3 Peak Assymetry}

Design points above predicted value

Design points below predicted value

$1.02 \square 1.99$

$\mathrm{X} 1=\mathrm{A}: \mathrm{A}$ Mobile Phase

$\mathrm{X} 2=\mathrm{B}: \mathrm{B} \mathrm{pH}$

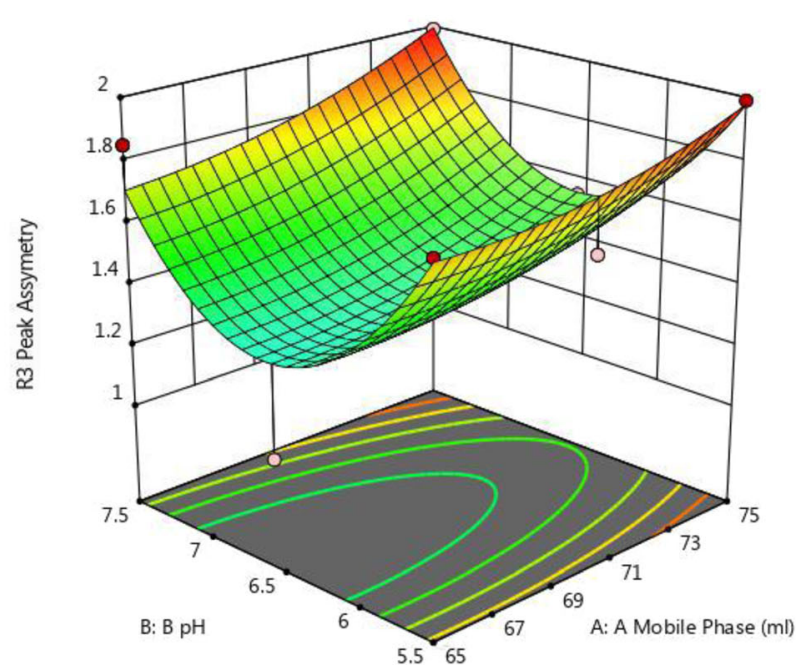

Fig. 3 3D surface plot for effect of combination of factors on R3 peak asymmetry of ceftriaxone sodium by using central composite design 
Table 3 Obtained solution for optimized formulation

\begin{tabular}{lllllll}
\hline Code & Acetonitrile to water & $\mathbf{p H}$ & Retention time & Theoretical plates & Peak asymmetry & Desirability \\
\hline $\mathrm{C} 10$ & $75: 25$ & 6.5 & 4.156 & 5836 & 1.55 & 0.765 \\
\hline
\end{tabular}

the quantification limit. The following equation was used to measure $\mathrm{LOD}$ and $\mathrm{LOQ}$ according to $\mathrm{ICH}$ guidelines.

$$
\begin{aligned}
& \mathrm{LOD}=3.3 \times \sigma / \mathrm{SD} \\
& \mathrm{LOQ}=10 \times \sigma / \mathrm{SD}
\end{aligned}
$$

where $\sigma$ is the standard deviation of the y-intercept of the regression line, and SD is the slope of the calibration curve.

\section{Robustness and ruggedness studies}

The method's robustness was calculated by subjecting the method to a minor change in the state of the method, such as pump flow rate and $\mathrm{pH}$ of mobile phase composition. The ruggedness studies were determined by changing the analyst as extraneous influencing factor. The acceptance limit for calculated \%RSD of peak area was less than 2.

\section{System suitability studies}

The system suitability was evaluated by six replicate analyses of ceftriaxone sodium. The retention time, column efficiency, peak asymmetry, and theoretical plates were calculated for standard solutions.

\section{Assay}

Twenty tablets were weighed and powdered. Weigh an accurately about powder equivalent to $100 \mathrm{mg}$ of ceftriaxone sodium, and transfer to $100 \mathrm{ml}$ of volumetric flask. Add $25 \mathrm{ml}$ of methanol, and perform sonication for 15 min until the powder dissolves. Then, make up the volume up to the mark with mobile phase. Filter the resulting solution with $0.42 \mu$ Whatman filter paper. From the filtrate, dilute $0.5 \mathrm{ml}$ to $10 \mathrm{ml}$ to have a concentration of $100 \mu \mathrm{g} / \mathrm{ml}$. The solution was analyzed by HPLC with same chromatographic condition as linearity. The mean of 3 different assay were used for calculation.

\section{Results}

Initially, a mobile phase acetonitrile to water, $50: 50 \mathrm{v} / \mathrm{v}$, was tried; the peak was observed at far retention time. No single peak was observed with mobile phase acetonitrile to water, $80: 20 \mathrm{v} / \mathrm{v}$. The further mobile phase tried was acetonitrile to water, 40:60 v/v. The improvement of peak shape and symmetry was done by adjusting

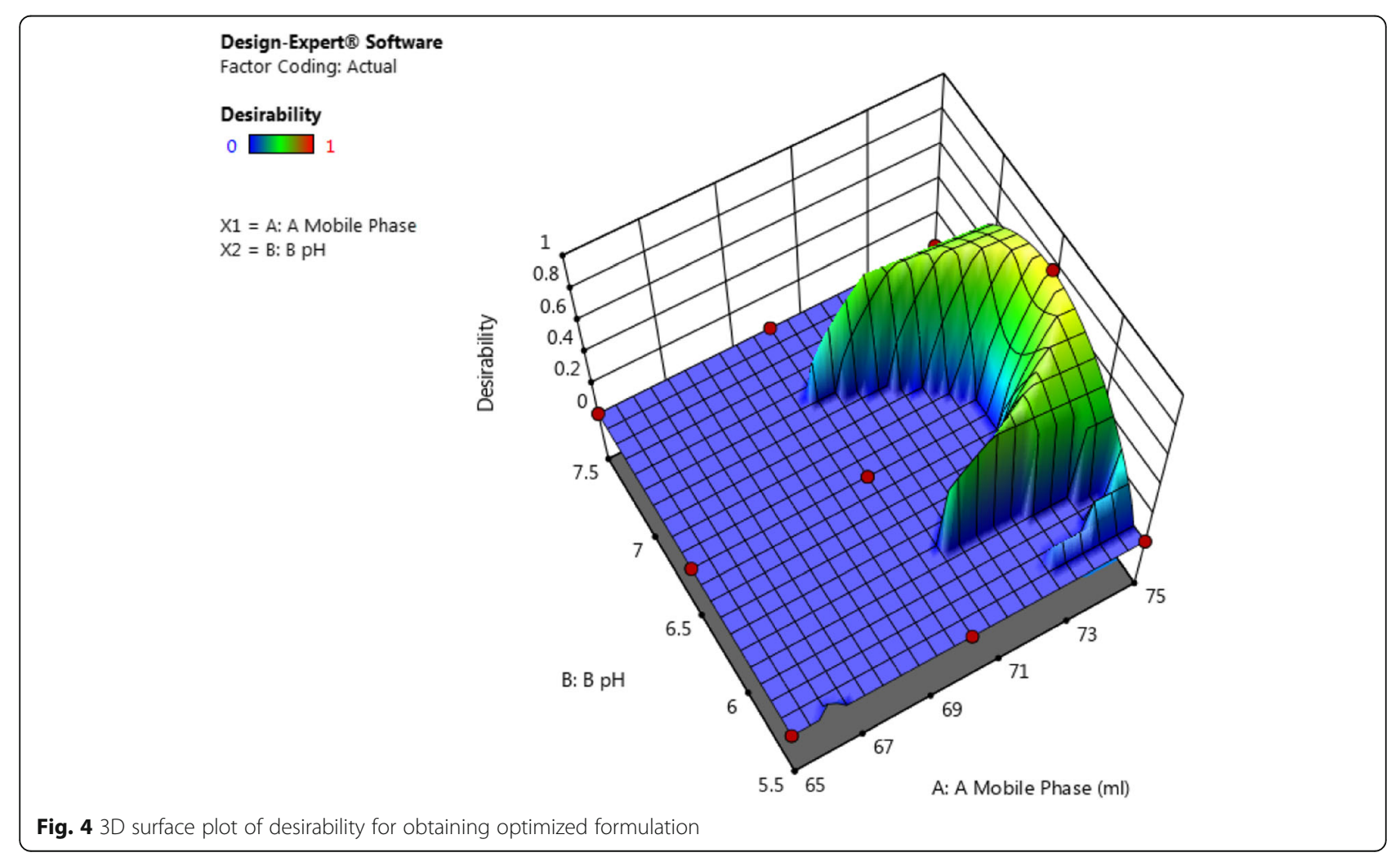


Table 4 Linearity of ceftriaxone sodium

\begin{tabular}{lll}
\hline Sr. no. & Concentration $(\boldsymbol{\mu g} / \mathbf{m l})$ & Peak area $($ mean \pm SD) $(\mathbf{n}=\mathbf{3})$ \\
\hline 1 & 10 & $837465 \pm 2542.14$ \\
2 & 50 & $1867745 \pm 2508.90$ \\
3 & 100 & $2714568 \pm 2223.56$ \\
4 & 150 & $3774522 \pm 1959.99$ \\
5 & 200 & $5268896 \pm 2697.17$ \\
\hline
\end{tabular}

the buffer $\mathrm{pH}$. The system suitability test parameters were satisfied with optimized chromatographic condition. The optimized mobile phase consisting of acetonitrile to water, $70: 30 \mathrm{v} / \mathrm{v}$, and $\mathrm{pH} 6.5$ adjusted with $0.01 \%$ triethylamine. The central composite design was used further for the optimization of various parameters within the design space.

\section{HPLC method development by QbD approach [25] Quality target product profile}

The QTPP selected were retention time, theoretical plates, and peak asymmetry for optimization of HPLC chromatographic condition.

\section{Critical quality attributes}

The mobile phase composition acetonitrile to water, 70: 30 , and $\mathrm{pH}$ of buffer solution adjusted with $0.01 \%$ triethylamine were identified.
Factorial design [21]

The CCD central composite design was selected for proposed HPLC method development. The optimization of various parameters is shown in Table 2.

\section{Design space}

The response surface study type, central composite design, and quadric design model with 11 runs were used. The proposed CCD experimental design was applied, and the evaluation of mobile phase composition and $\mathrm{pH}$ of buffer was done against the three responses, retention time, theoretical plates, and peak asymmetry, and the result was summarized.

From Fig. 1 and equation retention time (for actual values $)=56.75+0.028 \times \mathrm{A}-19.01 \times \mathrm{B}-0.010 \times \mathrm{AB}+$ $0.000343 \times \mathrm{A}^{2}+1.70458 \times \mathrm{B}^{2}$, it was concluded that as $\beta_{1}$ positive coefficient $(0.028)$ suggests that as the amount of acetonitrile in the mobile phase (A) increases and $\beta_{2}$ negative coefficient (-19.01) suggests that as $\mathrm{pH}$ of buffer (B) decreases, the value of retention time was increased.

From Fig. 2 and equation theoretical plates (for actual values $)=-16774.36-4220.40 \times \mathrm{A}+53225.20 \times \mathrm{B}+$ $56.05 \times \mathrm{A} \times \mathrm{B}+26.83 \times \mathrm{A}^{2}-4380.60 \times \mathrm{B}^{2}$, it was concluded that as $\beta_{1}$ negative coefficient $(-4220.40)$ suggests that as the amount of acetonitrile in the mobile phase (A) decreases and $\beta_{2}$ positive coefficient (53225.20) suggests that as $\mathrm{pH}$ of buffer (B) increases, the value of theoretical plates was increased

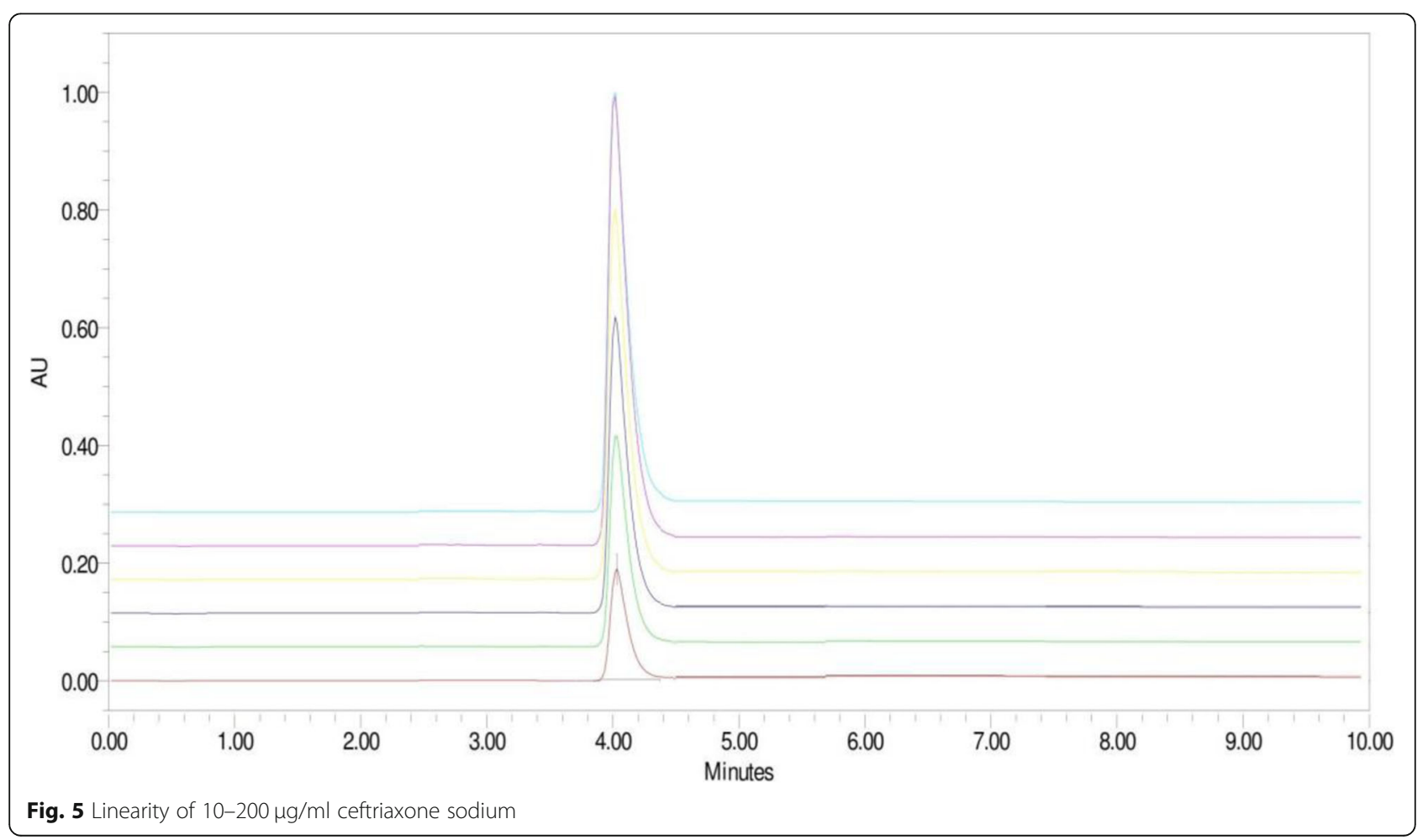


Table 5 Data for intraday and interday of ceftriaxone sodium

\begin{tabular}{llll}
\hline Precision period & Concentration $(\boldsymbol{\mu g} / \mathbf{m l})$ & (Mean \pm SD) $(\mathbf{n}=\mathbf{3})$ & \%RSD \\
\hline Intraday precision & 10 & $831995 \pm 7787$ & 0.94 \\
& 100 & $2736502 \pm 19105$ & 0.70 \\
Interday precision & 200 & $5252142 \pm 40415$ & 0.77 \\
& 10 & $839597 \pm 8001$ & 0.95 \\
& 100 & $2741235 \pm 19698$ & 0.72 \\
& 200 & $5249857 \pm 28661$ & 0.55 \\
\hline
\end{tabular}

From Fig. 3 and equation peak asymmetry (for actual values $)=31.13-0.31 \times \mathrm{A}-5.98 \times \mathrm{B}+0.0055 \times \mathrm{A} \times \mathrm{B}$ $+0.0021 \times A^{2}+0.429 \times B^{2}$, it was concluded that as $\beta_{1}$ negative coefficient $(-0.31)$ suggests that as the amount of acetonitrile in the mobile phase (A) decreases and $\beta_{2}$ negative coefficient $(-5.98)$ suggests that as $\mathrm{pH}$ of buffer (B) decreases, the value of peak asymmetry was increased.

\section{Optimized condition obtained}

It was obtained by studying all responses in different experimental conditions using the Design expert 11.0 software, and optimized HPLC conditions and predicted responses are shown in Table 3.

The observed value for responses was calculated by running the HPLC chromatogram for given set of mobile phase and $\mathrm{pH}$ of buffer and then compared with the predicted values to evaluate for $\%$ prediction error.

\section{Method validation}

\section{System suitability}

The system suitability test was applied to a representative chromatogram to check the various parameters such as the retention time which was found to be $4.15 \mathrm{~min}$, theoretical plates were 5263, peak asymmetry was 1.49 , and \% RSD of six replicate injections was 0.82 . The 3D surface plot of desirability for obtaining optimized formulation is shown Fig. 4.

\section{Linearity}

The constructed calibration curve for ceftriaxone sodium was linear over the concentration range of 10$200 \mu \mathrm{g} / \mathrm{ml}$ shown in Fig. 2 and Table 4. Typically, the regression equation for the calibration curve was found to be $y=35441 x+60368$ with a 0.991 correlation coefficient when graph was plotted with peak area verses concentration (Fig. 5).

\section{Precision}

The \% RSD for repeatability for ceftriaxone sodium based on six times the measurement of the same concentration $(100 \mu \mathrm{g} / \mathrm{ml})$ was found to be less than 0.082 . Interday and intraday precisions were shown in Table 5. The \% RSD value less than 2 indicated that the developed method was found to be precise.

\section{Accuracy}

The accuracy was done by recovery study. Sample solutions were prepared by spiking at 3 levels, i.e., $80 \%$, $100 \%$, and $120 \%$. The $\%$ recovery data obtained by the proposed HPLC method are shown in Table 6 . The \% of recovery within 98-102\% justify the developed method was accurate as per the ICH Q2 (R1) guidelines.

\section{Robustness and ruggedness studies}

For robustness and ruggedness studies $100 \mu \mathrm{g} / \mathrm{ml}$ solution of ceftriaxone sodium was used. The robustness was studied by the slight but deliberate change in intrinsic method parameters like $\mathrm{pH}$ of mobile phase and flow rate. The ruggedness was studied by change in analyst as extraneous influencing factor. The \% RSD for peak area were found to be less than 2 by change in $\mathrm{pH}$ of mobile phase, flow rate, and analyst.

\section{$\angle O D$ and $\angle O Q$}

The LOD and LOQ for ceftriaxone sodium based on standard deviation of slope and intercept were found to be $0.22 \mu \mathrm{g} / \mathrm{ml}$ and $0.67 \mu \mathrm{g} / \mathrm{ml}$ respectively.

Table 6 Recovery of ceftriaxone sodium

\begin{tabular}{|c|c|c|c|c|c|}
\hline $\begin{array}{l}\text { Assay } \\
\text { level }\end{array}$ & $\begin{array}{l}\text { Amount equivalent to tablet } \\
\text { powder(mg) }\end{array}$ & $\begin{array}{l}\text { Standard added } \\
(\mathrm{mg})\end{array}$ & $\begin{array}{l}\text { Total amount } \\
\text { (mg) }\end{array}$ & $\begin{array}{l}\text { Recovered amount }(\mathrm{mg}) \pm \\
\text { SD }(\mathrm{n}=3)\end{array}$ & $\begin{array}{l}\text { \% Recovered spiked amount } \pm \\
\text { SD }(n=3)\end{array}$ \\
\hline Blank & 50 & 00 & 50 & $50.59 \pm 0.71$ & $101.19 \pm 1.42$ \\
\hline $80 \%$ & 50 & 40 & 90 & $40.17 \pm 0.70$ & $100.79 \pm 1.73$ \\
\hline $100 \%$ & 50 & 50 & 100 & $49.24 \pm 0.43$ & $99.57 \pm 1.47$ \\
\hline $120 \%$ & 50 & 60 & 110 & $59.63 \pm 0.42$ & $99.70 \pm 1.40$ \\
\hline
\end{tabular}




\section{Assay}

The optimized chromatogram ceftriaxone sodium showed a resolved peak at retention time $4.15 \mathrm{~min}$ when performed assay from tablets. The \% assay of drug content was found to be $99.73 \pm 0.61(n=3)$ for label claim of ceftriaxone sodium. The assay result indicated the method's ability to measure accurately and specifically in presence of excipients presents in tablet powder.

\section{Discussion}

The analytical quality-by-design HPLC method for the estimation of ceftriaxone sodium in pharmaceutical formulation has been developed. The analytical target product profile were retention time, theoretical plates, and peak asymmetry for the analysis of ceftriaxone sodium by HPLC. The two variables namely the mobile phase composition and $\mathrm{pH}$ of buffer solution were identified as the critical quality attributes that affect the analytical target product profile. The central composite design was applied for two factors at three different levels with the use of the Design Expert Software Version 11.0. The risk assessment study identified the critical variables that have impact on analytical target profile [26-28]. In chromatographic separation, the variability in column selection, instrument configuration, and injection volume was kept controlled while variables such as $\mathrm{pH}$ of mobile phase, flow rate, and column temperature were assigned to robustness study.

The quality-by-design approach successfully developed the HPLC method for ceftriaxone sodium. The optimized RP-HPLC method for determination of ceftriaxone sodium used Phenomenex C18 column (250 $\times 4.6 \mathrm{~mm}, 5 \mu \mathrm{m}$ particle size) and mobile phase consist of acetonitrile to water, $70: 30 \mathrm{v} / \mathrm{v}, \mathrm{pH}$ adjusted to 6.5 with $0.01 \%$ triethylamine buffer. The retention time for ceftriaxone sodium was found to be 4.15 min. The method was linear in the range of 10$200 \mu \mathrm{g} / \mathrm{ml}$ with 0.991 correlation coefficient. The \% RSD for repeatability, intraday, and inter day precision was found to be less that $2 \%$ indicating the optimized method was precise. The LOD and LOQ were $0.22 \mu \mathrm{g} / \mathrm{ml}$ and $0.67 \mu \mathrm{g} / \mathrm{ml}$, respectively. The \% recovery of spiked samples was found to be $99.57 \pm 1.47$ to $100.79 \pm 1.73$ as per the acceptance criteria of the $\mathrm{ICH}$ guidelines. The method was developed as per the $\mathrm{ICH}$ guidelines.

\section{Conclusion}

A quality-by-design approach to HPLC method development has been described. The method goals are clarified based on the analytical target product profile. The experimental design describes the scouting of the key HPLC method components including mobile phase and
$\mathrm{pH}$. The analytical QbD concepts were extended to the HPLC method development for ceftriaxone sodium, and to determine the best performing system and the final design space, a multivariant study of several important process parameters such as the combination of 2 factors namely the mobile phase composition and $\mathrm{pH}$ of buffer at 3 different levels was performed. Their interrelationships were studied and optimized at different levels using central composite design. Here, a better understanding of the factors influencing chromatographic separation in the ability of the methods to meet their intended purposes is done. This approach offers a practical knowledge understanding that help for the development of a chromatographic optimization that can be used in the future. All the validated parameters were found within the acceptance criteria. The validated method was found to be linear, precise, accurate, specific, robust, and rugged for determination of ceftriaxone sodium. The QbD approach to method development has helped to better understand the method variables hence leading to less chance of failure during method validation and transfer. The automated QbD method development approach using the Design Expert software has provided a better performing more robust method in less time compared to manual method development. The statistical analysis of data indicates that the method is reproducible, selective, accurate, and robust. This method will be used further for routine analysis for quality control in pharmaceutical industry.

\section{Abbreviations \\ QbD: Quality by design; API: Active pharmaceutical ingredient; CCD: Central composite design; QTPP: Quality target product profile; CQA: Critical quality attribute; HPLC: High-performance liquid chromatography; RP HPLC: Reverse phase high-performance liquid chromatography; LOQ: Limit of quantitation; LOD: Limit of detection; RSD: Relative standard deviation}

\section{Acknowledgements}

All authors are very thankful to the Bhagwan Mahavir College of Pharmacy, Surat, for providing necessary facilities to carry out the research work.

\section{Authors' contributions}

All authors associated with this research work declared that there is no conflict of interest for publication of work. All authors have read and approved the manuscript. The contribution of each author is mentioned below. KP: He is a M Pharm (Quality Assurance) Research Student and the above work has been carried out by him as dissertation work. ZD: She is Research Guide and HOD, Department of Quality Assurance and under her noble guidance the QbD approach for HPLC method has been developed and validated as per $\mathrm{ICH}$ guidelines. She is also giving training for ease of operation sophisticated instrument and involved in interpretation of data. $\mathrm{RD}$ : He is a co-guide and under his noble guidance student can understand the Design Expert Software and interpretation of statistical data. UP: She is a graduate teaching assistant at University of Alabama at Huntsville, USA and she has contributed for preparing the manuscript.

Funding

This research did not receive any specific grant from funding agencies in the public, commercial, or not-for-profit sectors.

Availability of data and materials

All data and material are available upon request. 


\section{Declarations}

Ethics approval and consent to participate

Not applicable

\section{Consent for publication}

Not applicable

\section{Competing interests}

No competing interests to declare.

\section{Author details}

'Department of Quality Assurance, Bhagwan Mahavir College of Pharmacy, Vesu, Surat, Gujarat, India. ${ }^{2}$ Department of Chemistry, The University of Alabama in Huntsville, 301 Sparkman Dr, Huntsville AL-35899, USA.

Received: 4 December 2020 Accepted: 18 June 2021

Published online: 13 July 2021

\section{References}

1. Sandipan R (2012) Quality by design: A holistic concept of building quality in pharmaceuticals. Int J Pharm Biomed Res 3:100-108

2. The International Conference on Harmonisation ICH Technical Requirements for Registration of Pharmaceuticals for Human Use on Pharmaceutical Development Q8(R2) (2009) https://database.ich.org/sites/default/files/Q8\%2 8R2\%29\%20Guideline.pdf

3. The International Conference on Harmonisation ICH Technical Requirements for Registration of Pharmaceuticals for Human Use on Quality Risk Management Q9 (2005) https://database.ich.org/sites/default/files/Q9\%2 oGuideline.pdf

4. The International Conference on Harmonisation ICH Technical Requirements for Registration of Pharmaceuticals for Human Use on Pharmaceutical Quality System Q10 (2008) https://database.ich.org/sites/default/files/Q10\%2 OGuideline.pdf

5. Borman $P$, Nethercote $P$, Chatfield M, Thompson D, Truman K (2007) The application of quality by design to analytical methods. Pharm Tech 31:142152

6. Schweitzer M, Pohl M, Hanna BM, Nethercote P, Borman P, Hansen G, Smith K, Larew J (2010) Implications and opportunities of applying QbD principles to analytical measurements. Pharm Tech 34:52-59

7. Galen WE (2004) Analytical Instrumentation Handbook 2nd edn. Marcel Dekker Inc, New York

8. Snyder LR, Kirkland JJ, Glajch LJ (1997) Practical HPLC method development 2nd edn. John Wiley \& Sons Inc, New York. https://doi.org/10.1002/978111 8592014

9. Bhatt D, Rane S (2011) QbD approach to analytical RP-HPLC method development and its validation. Int J Pharm Pharm Sci 3:79-187

10. Rajkotwala A, Shaikh S, Dedania Z, Dedania R, Vijyendraswamy S (2016) QbD approach to analytical method development and validation of piracetam by HPLC. World J Pharmacy Pharmaceutical Sci 5:1771-1784

11. Singh P, Maurya J, Dedania Z, Dedania R (2017) QbD Approach for stability indicating HPLC method for determination of artemether and lumefantrine in combined dosage form. Int J Drug Reg Affairs 5:44-59

12. Prajapati R, Dedania Z, Jain V, Sutariya V, Dedania R, Chisti Z (2019) QbD approach to HPLC method development and validation for estimation of fluoxetine hydrochloride and olanzapine in pharmaceutical dosage form. J Emerging Tech Innovative Res 6:179-195

13. Dhand V, Dedania Z, Dedania R, Nakarani K (2020) QbD approach to method development and validation of orciprenaline sulphate by HPLC. J Global Trends Pharm Sci 11:8634-8640

14. Krull I, Swartz M, Turpin J, Lukulay P, Verseput R (2008) A quality-by-design methodology for rapid LC method development, part I. Liq Chroma Gas Chroma N Am 26:1190-1197

15. Myers R, Montgomery D, Anderson-Cook C (2016) Response surface methodology: process and product optimization using designed experiments. 4th edn. New York: Wiley

16. Yubing T (2011) Quality by design approaches to analytical methods- FDA perspective. https://www.fda.gov/files/about\%20fda/published/Quality-byDesign-Approaches-to-Analytical-Methods\%2D\%2D\%2D\%2DFDAPerspective\%2D\%2DYubing-Tang\%2D\%2DPh.D.\%2D\%2DOctober\%2D\%2D2 011\%2D\%2DAAPS-Annual-Meeting.pdf. Accessed 15 Dec 2018.
17. Krull I, Swartz M, Turpin J, Lukulay P, Verseput R (2009) A quality-by-design methodology for rapid LC method development part II. Liq Chroma Gas Chroma N Am 27:48-69

18. Reid G, Morgado J, Barnett K, Harrington B, Wang J, Harwood J, Fortin D (2013) Analytical QbD in pharmaceutical development. https://www.waters. com/nextgen/in/en/library/application-notes/2019/analytical-quality-bydesign-based-method-development-for-the-analysis-of-formoterolbudesonide-and-related-compounds-using-uhplc-ms.html. Accessed 10 June 2018.

19. Molnar RH, Monks K (2010) Aspects of the "Design Space" in high pressure liquid chromatography method development. J Chromatogra A 1217(19): 3193-3200. https://doi.org/10.1016/j.chroma.2010.02.001

20. Monks K, Molnar I, Rieger H, Bogati B, Szabo E (2012) Quality by design: multidimensional exploration of the design space in high performance liquid chromatography method development for better robustness before validation. J Chromatogra A 1232:218-230. https://doi.org/10.1016/j. chroma.2011.12.041

21. Ramalingam P, Kalva B, Reddy Y (2015) Analytical quality by design: a tool for regulatory flexibility and robust analytics. Int J Ana Chem. https://doi. org/10.1155/2015/868727

22. The International Conference on Harmonisation ICH Technical Requirements for Registration of Pharmaceuticals for Human Use on Development and Manufacture of Drug Substances (Chemical Entities and Biotechnological/ Biological Entities) Q11 (2012) https://database.ich.org/sites/default/files/ Q11\%20Guideline.pdf

23. Orlandini S, Pinzauti S, Furlanetto S (2013) Application of quality by design to the development of analytical separation methods. Ana Bioana Chem 405(2-3):443-450. https://doi.org/10.1007/s00216-012-6302-2

24. The International Conference on Harmonisation ICH Technical Requirements for Registration of Pharmaceuticals for Human Use on Validation of Analytical Procedures: Text and Methodology Q2(R1) (2005) https://databa se.ich.org/sites/default/files/Q2\%28R1\%29\%20Guideline.pdf

25. Reid G, Cheng G, Fortin D (2013) Reversed-phase liquid chromatographic method development in an analytical quality by design framework. J Liq Chrom Related Tech 36(18):2612-2638. https://doi.org/10.1080/10826076.2 013.765457

26. Elder $P$, Borman $P$ (2013) Improving analytical method reliability across the entire product lifecycle using QbD approaches. Pharmaceu Outsourcing, 14 14-19. http://www.pharmoutsourcing.com/Featured-Articles/142484Improving-Analytical-Method-Reliability-Across-the-Entire-Product-LifecycleUsing-QbD-Approaches/. Accessed 2019.

27. Smith J, Jones M Jr, Houghton L (1999) Future of health insurance. N Engl J Med 965:325-329

28. Schweitzer M, Pohl M, Hanna-Brown M (2010) Implications and opportunities of applying QbD principles to analytical measurements. Pharmaceu Tech 34:52-59

\section{Publisher's Note}

Springer Nature remains neutral with regard to jurisdictional claims in published maps and institutional affiliations.

\section{Submit your manuscript to a SpringerOpen ${ }^{\circ}$ journal and benefit from:}

- Convenient online submission

- Rigorous peer review

- Open access: articles freely available online

- High visibility within the field

- Retaining the copyright to your article

Submit your next manuscript at $>$ springeropen.com 